\title{
Uptake of Heavy Metals by Dioscorea rotundata (White Yam) and Ipomoea batatas (Sweet Potato) from Enyigba Lead-Zinc Derelict
}

\author{
Oti Wilberforce, J. O. ${ }^{1} \&$ Nwabue, F. I. ${ }^{1}$ \\ ${ }^{1}$ Department of Industrial Chemistry, Ebonyi State University, Nigeria \\ Correspondence: Oti Wilberforce, J. O., Department of Industrial Chemistry, Ebonyi State University, Private \\ Mail Bag 053, Abakaliki, Nigeria. E-mail: otiwilberforce@gmail.com; oti_wbf@yahoo.com. Tel: \\ 234-803-549-9433 \\ Received: July 27, 2012 Accepted: January 11, 2013 Online Published: March 27, 2013 \\ doi:10.5539/ep.v2n2p79 URL: http://dx.doi.org/10.5539/ep.v2n2p79
}

\begin{abstract}
The levels of heavy metals in Dioscorea rotundata (white yam) and Ipomoea batatas (sweet potato), in addition to the soil, were examined using X-ray Fluorescence (XRF) technique. The results revealed that heavy metal in soil decreased in the order $\mathrm{Pb}>\mathrm{Zn}>\mathrm{Cu}>\mathrm{Mn}>\mathrm{Cd}>\mathrm{Ni}>\mathrm{As}>\mathrm{Cr}$. The mean concentration $\left(\mathrm{mg} \mathrm{kg}^{-1}\right)$ of metals was found in the range of $\mathrm{Pb}$ (0.04-0.14); As (0.02-0.04): $\mathrm{Cd}$ (0.02-0.04); $\mathrm{Cu}$ (40.12-62.12); $\mathrm{Cr}$ (0.01-0.21); $\mathrm{Zn}$ (24.18-74.60); (Mn 18.46-84.90); and Ni (8.24-14.86). As and Cd were not detected in leaves of Dioscorea rotundata. Generally accumulation of metals was observed to be higher in the root than in the leaves and the Translocation Factor (TF) was highest (2.0) in Ipomoea batatas and lowest (0.22) in Dioscorea rolundala. High Pollution Indices ( $\mathrm{PI}>1$ ) of $\mathrm{As}$ and $\mathrm{Pb}$ was observed in the two investigated tubers. The variation in the parameters determined were found to be statistically significant $(p<0.05)$ as determined by one way analysis of variance.
\end{abstract}

Keywords: heavy metals, tuber crops, X-ray fluorescence, Enyigba lead-zinc derelict

\section{Introduction}

Increasing industrialization has been accompanied throughout the world by the extraction and distribution of mineral substances from their natural deposits (Sing, 2001). Unlike many other pollutants associated with the environments, metals are non-biodegradable and can undergo biomagnifications in living tissues (Clark, 1992). Uptake and accumulation of heavy metals by plants is either via the roots and foliar surfaces (Sawidis et al., 2001). Some factors which affect metal uptake include soil $\mathrm{pH}$, metal solubility, conductivity, stages of plant growth, plant species, soil type and fertilizers (Sharma et al., 2006; Ismail et al., 2005). Previous work by Kaplan et al. (2005) showed that individual plants have different capacity to absorb and accumulate heavy metals which leads to contamination of the food chain. This situation causes varying degrees of illness based on acute and chronic exposures (Demirezen \& Ahmet, 2006). The present study was carried out within the vicinity of a lead zinc derelict mine, Enyigba in South East Nigeria where farmers cultivate their crops around the mine waste. The contamination status of many edible plants from Enyigba is yet to be established. Previous works in Enyigba by Nweke et al. (2008) and Chukwuma (1993) focused on soils and wild plants respectively. Tuber crops such as Dioscorea rotundata and Ipomoea batata are very common in Enyigba and its environs. Mothers often fry these tubers and serve as breakfast to young children. The aims of this study are in two fold; first, establish the Pollution Index or contamination status of the investigated tubers by comparing the concentration of $\mathrm{As}, \mathrm{Cd}, \mathrm{Pb}$, $\mathrm{Zn}, \mathrm{Cu}, \mathrm{Cr}, \mathrm{Mn}$, and $\mathrm{Ni}$ in the tubers with the World Health Organization (WHO) Maximum Allowable Limit. Second, establish Translocation Factor (TF) of the tubers by comparing the concentrations of metals in roots with those in the leaves of the tubers. Translocation Factor reveals the plant's ability to translocate heavy metals from the root to aerial part is used to evaluate the plants potential for phytoremediation purposes (Mattina et al., 2003).

\section{Materials and Methods}

\subsection{Study Area}

Enyigba is located approximately $14 \mathrm{~km}$ South of Abakaliki, the capital of Ebonyi State, Nigeria and has a sparse rural population of farmers. The prevailing climate conditions are high temperatures, high atmospheric humidity and precipitation usually exceeding evapotranspiration. The vegetation types are mangrove and freshwater swamp 
communities, rainforest, forest/savanna mosaic and derived savanna zone. The farming systems prevailing in the region are dominated by yam/root crops/plantain, oil palm bush and indigenous trees of nutritional economic, medicinal and cultural importance. Mining of lead began around 1925 but was interrupted by the Nigerian civil war and as a result many villagers have resorted to cultivating their economic plants around the derelict properties (Oti et al., 2012).

\subsection{Sampling}

Dioscorea rotundata and Ipomoea batatas were selected for the analysis because they form staple food consumed by the masses on a daily basis (Taiwo, 1985). Composite samples of the plants and soil were collected within a 200 meter radius of the mine.

Soil sample pre-treatment: Soil samples were air-dried, mechanically ground and sieved to obtain $<2 \mathrm{~mm}$ fraction. A $30 \mathrm{~g}$ subsample was drawn from the bulk soil ( $<2 \mathrm{~mm}$ fraction) and reground to obtain $<200 \mu \mathrm{m}$ fraction using a mortar and pestle.

Plant sample pre-treatment: The roots and leaves of the Dioscorea rotundata and ipomoea batatas were separated in each case and the components were cut into pieces. Samples were then put through a three step washing sequence, air dried, weighed and placed in a dehydrator at $80{ }^{\circ} \mathrm{C}$ for 48 hours. The moisture and water droplets were removed with the help of blotting papers. The sample was pulverized into fine powdery form by the use of an agate mortar.

Sample analysis: Standard Operating Procedure for XRF was followed in accordance with Shefsky (1995) and Galadima and Garba (2012). A $13 \mathrm{~mm}$ pellet of the sample was formed using CAVER model manual palletizing machine at a pressure of 6-8 torr. A voltage of $25 \mathrm{KV}$ and current of $50 \mu \mathrm{A}$ produced from X-ray tube was used to bombard the sample in XRF system for 18 minutes at 1000 counts. Si-Li detector was used to detect the characteristic X-ray of the metals and their corresponding concentrations were computed in the read out device.

\section{Results}

Table 1 shows the mean concentration of heavy metals in soil with their corresponding pollution indices while Table 2 shows the properties of the soil respectively. Values shown in Tables 1 and 2 are mean \pm Standard Deviation. Tables 3, 4 and 5 illustrate the levels, the Translocation Factor and the Pollution Indices of heavy metals in the investigated tubers, respectively. Figures 1,2 and 3 show the Translocation Factors of heavy metals and the Pollution Indices of the roots and leaves of the investigated plants, respectively.

Table 1. Mean concentrations $(\mathrm{mg} / \mathrm{kg})$ of heavy metals in soil and their pollution indices $(\mathrm{n}=3)$

\begin{tabular}{ccccccccc}
\hline Metals & $\mathrm{Pb}$ & $\mathrm{As}$ & $\mathrm{Cd}$ & $\mathrm{Cu}$ & $\mathrm{Cr}$ & $\mathrm{Zn}$ & $\mathrm{Mn}$ & $\mathrm{Ni}$ \\
\hline Conc $(\mathrm{mg} / \mathrm{kg})$ & $1116.8 \pm 43.2$ & $4.8 \pm 1.8$ & $126.0 \pm 42.1$ & $812.2 \pm 141.2$ & $2.12 \pm 0.2$ & $995.2 \pm 82.4$ & $424.0 \pm 50.4$ & $82.6 \pm 22.0$ \\
PI & 2.7 & 0.06 & 1.5 & 0.19 & - & 0.13 & - & 1.1 \\
USEPA & 420 & 75 & 85 & 4300 & - & 75000 & $1-1830 *$ & 75 \\
\hline
\end{tabular}

*Values refer to metal concentration in typical soils (Miroslav \& Vladimir, 1999), PI = Pollution index.

Table 2. Properties of Enyigba soil

\begin{tabular}{cc}
\hline Properties & Enyigba soil $(\mathrm{n}=3)$ \\
\hline Sand (\%) & $61.28 \pm 5.2$ \\
Silt (\%) & $7.12 \pm 0.8$ \\
Clay (\%) & $31.60 \pm 2.6$ \\
Organic matter (\%) & $1.34 \pm 0.5$ \\
Mean pH & $6.80 \pm 0.38$ \\
\hline
\end{tabular}


Table 3. Levels of heavy metals in the leaves and root of Dioscorea rotundata and Ipomoea batatas and their translocation factor

\begin{tabular}{ccccccccccccc}
\hline \multicolumn{10}{c}{ Heavy metals concentration $(\mathrm{mg} / \mathrm{kg})(\mathrm{n}=3)$} \\
\hline Botanical name & $\begin{array}{c}\text { Common } \\
\text { Name }\end{array}$ & Plant parts & $\mathrm{Pb}$ & $\mathrm{As}$ & $\mathrm{Cd}$ & $\mathrm{Cu}$ & $\mathrm{Cr}$ & $\mathrm{Zn}$ & $\mathrm{Mn}$ & $\mathrm{Ni}$ \\
\hline Dioscorea rotundata & White yam & Leaves & 0.21 & $\mathrm{ND}$ & $\mathrm{ND}$ & 42.12 & 0.01 & 24.18 & 18.46 & 12.42 \\
& & Root & 0.41 & 0.12 & 0.02 & 40.12 & 0.01 & 62.43 & 82.62 & 14.86 \\
Translocation Factor & & & 0.51 & - & - & 1.05 & 1.0 & 0.39 & 0.22 & 0.84 \\
Ipomoea batatas & Sweet & Leaves & 0.04 & 0.02 & 0.04 & 62.12 & 0.21 & 46.12 & 28.12 & 8.24 \\
& Potato & Root & 0.12 & 0.14 & 0.02 & 42.24 & 0.18 & 74.60 & 84.90 & 10.24 \\
Translocation Factor & & & 0.33 & 0.14 & 2.0 & 1.47 & 1.17 & 0.62 & 0.33 & 0.81 \\
\hline
\end{tabular}

$\mathrm{ND}=$ Not Detected

Table 4. Pollution indices of heavy metals in Dioscorea rotundata and Ipomoea batatas

\begin{tabular}{|c|c|c|c|c|c|c|c|c|c|c|}
\hline \multicolumn{11}{|c|}{ Pollution Indices } \\
\hline $\begin{array}{c}\text { Botanical } \\
\text { Name }\end{array}$ & $\begin{array}{l}\text { Common } \\
\text { Name }\end{array}$ & Plant parts & $\mathrm{Pb}$ & As & $\mathrm{Cd}$ & $\mathrm{Cu}$ & $\mathrm{Cr}$ & $\mathrm{Zn}$ & $\mathrm{Mn}$ & $\mathrm{Ni}$ \\
\hline \multirow[t]{2}{*}{ Dioscorea rolundala } & White yam & Leaves & 0.7 & - & - & 0.56 & 0.2 & 0.24 & 0.04 & 0.19 \\
\hline & & Root & 1.37 & 1.2 & 0.2 & 0.55 & 0.2 & 0.62 & 0.17 & 0.22 \\
\hline \multirow[t]{2}{*}{ Ipomoea batatas } & & Leaves & 0.13 & 0.2 & 0.4 & 0.85 & 4.2 & 0.46 & 0.06 & 0.12 \\
\hline & Potato & Root & 0.4 & 1.4 & 0.2 & 0.58 & 3.6 & 0.75 & 0.17 & 0.15 \\
\hline WHO/FAO & Maximum & Limit & 0.3 & 0.1 & 0.1 & 73 & 0.05 & 100 & 500 & 67 \\
\hline
\end{tabular}

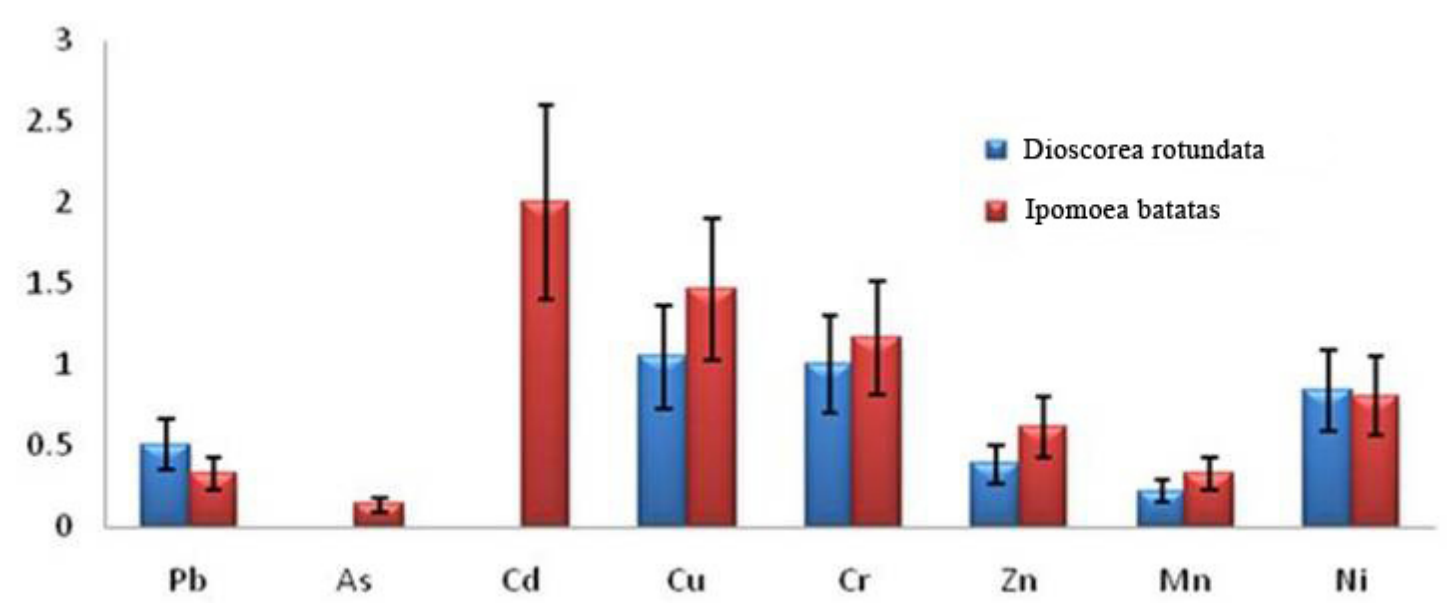

Figure 1. Translocation factors of heavy metals in Dioscorea rotundata and Ipomoea batatas 


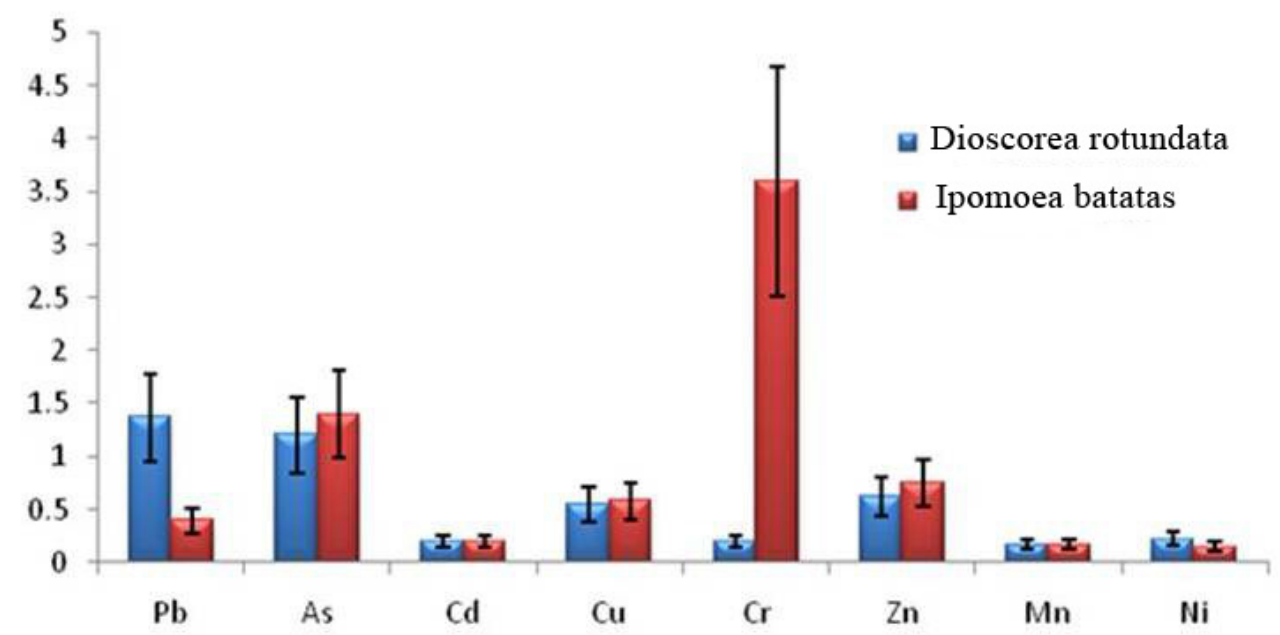

Figure 2. Pollution indices of roots of Dioscorea rotundata and Ipomoea batatas

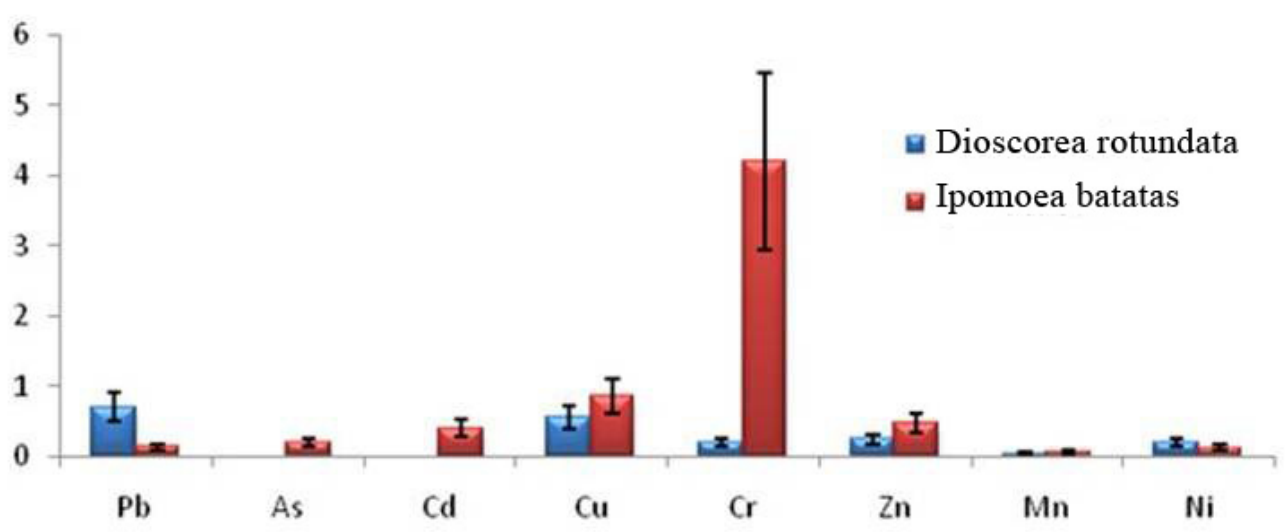

Figure 3. Pollution indices of leaves of Dioscorea rotundata and Ipomoea batatas

Trace metal levels in soil decreased in the order $\mathrm{Pb}>\mathrm{Zn}>\mathrm{Cu}>\mathrm{Mn}>\mathrm{Cd}>\mathrm{Ni}>\mathrm{As}>\mathrm{Cr}$ (Table 1). Table 2 illustrates that mean $\mathrm{pH}$ of soils was 6.8 indicating that the soil environment is neutral. The availability of nutrients for plants is directly influenced by soil $\mathrm{pH}$. Since tuber crops have been established to do best in slightly acidic soils of 5.8-6.4 $\mathrm{pH}$ (CU-DA Bulletin, 1994), suggesting that these categories of crop will not grow well in the study area unless something is done to reduce the $\mathrm{pH}$ value. Data obtained from this analysis suggests that Enyigba soils were polluted with $\mathrm{Pb}, \mathrm{Cd}$ and $\mathrm{Ni}$ having their pollution indices as 2.7, 1.5 and 1.1 respectively (Table 1, Figures 2 and 3). Lower concentrations of the studied metals were observed in unpolluted soil samples of Abakaliki, and their corresponding pollution indices were low (Oti et al., 2012). Accumulation of metals in roots was found to be higher than in the leaves (Table 3). High PI value of $\mathrm{Pb}$ in white yam suggests that the tuber were already contaminated with $\mathrm{Pb}$ (Table 4). A recent study in Zamfara State, Nigeria of environmental $\mathrm{Pb}$ poisoning of youths and children of a community engaged in artisanal mining resulted in deaths of 163 people between March and June 2010 (The Punch, 25th December, 2012). Demirezen and Ahmet (2006) observed a high concentration of $\mathrm{Pb}$ ranging between $3.0 \mathrm{mg} / \mathrm{kg}-10.7 \mathrm{mg} / \mathrm{kg}$ in a similar study done in Turkey. At $95 \%$ confidence level $(\mathrm{p}<0.05)$, it was discovered Translocation Factor of the studied metals in Dioscorea rotundata was significantly higher than in Ipomoea batatas. Their results contradict Muhammad et al. (2008) where concentration of $\mathrm{Pb}$ was observed to be higher in leaves than in roots of the plants. Lead uptake is promoted by the $\mathrm{pH}$ of soils and organic matter. Toxicological effects of $\mathrm{Pb}$ on humans include inhibition of hemoglobin formation, sterility, hypertension and mental retardation in children (Amdur, 1991). Pollution Index of As in roots of Dioscorea rotundata and Ipomoea batatas were $>1$ (Table 4, Figure 2 and 3) suggesting As contamination of affected tubers. Arsenic toxicity like $\mathrm{Pb}$, affects not only the central nervous system, but the 
gastrointestinal dysfunctions (ASTDR, 2010). According to Alam et al. (2003), high values of As were recorded in plants grown in polluted sites in Bangladesh. Highest values of Translocation Factor was observed in Ipomoea batatas for $\mathrm{Cd}(2.0)$ suggesting that tubers have a greater ability to transfer $\mathrm{Cd}$ from the root to the leaves. Cadmium is known to accumulate in kidneys where it damages filtering mechanisms. It takes a very long time before cadmium that has accumulated in kidneys is excreted from a human body (Jennings, 2005).

The PI of $\mathrm{Cu}$ in the two tubers from Enyigba was $<1$ (Table 4, Figures 2 and 3). Copper is an essential trace element in plants and animals. The human body contains copper at a level of about 1.4 to $2.1 \mathrm{mg} \mathrm{kg}^{-1}$ of body mass. However, chronic (long-term exposure) affects of $\mathrm{Cu}$ exposure can damage the liver and kidneys (USEPA, 2010). The PI of $\mathrm{Cr}$ in Ipomoea batatas was $>1$ while that of Dioscorea rotundata was $<1$ (Table 4, Figures 2 and 3). TF of Cr in Ipomoea batatas was found to be higher than in Dioscorea rotundata. Morishima and Oka (1980) reported high uptake of $\mathrm{Cr}$ in plant grown in polluted soils. The PI of $\mathrm{Mn}, \mathrm{Zn}$ and $\mathrm{Ni}$ in the investigated tubers were found to be $<1$ implying that their levels in the tubers have not reached a critical point. Critical point is reached when PI = 1 (Miroslav \& Vladimir, 1999).

\section{Conclusion}

This study provides a baseline data for further research in this part of the country ravaged by mining activities. The concentrations of metals were observed to be high in the tubers with levels of As and Pb exceeding WHO maximum limit in Dioscorea rotundata. Similarly As exceeded WHO maximum limit in Ipomoea batatas. Consumption of these tubers over a period of time may result to bioaccumulation of these toxic metals which can lead to adverse health effect or even death. On the other hand, hyperaccumulation of these metals indicates the potential of these plants as bioindicators and phytoremediation agents for environmental monitoring and cleaning up of polluted sites respectively. Further studies on the socio-economic and health status of the neighboring communities will provide more insight on the overall impact of mining activities.

\section{Acknowledgements}

The authors are grateful for the support and input of Dr. Mrs. C. D. Nnamani of Applied Biology Department of Ebonyi State University, Abakaliki, Nigeria for authenticating our plant samples and Mr Godwin Eze of Center for Energy Research and Development, Obafemi Awolowo University, Ile-Ife, Osun State, Nigeria for his priceless contribution in the XRF facilities at the Center.

\section{References}

Alam, M. G. M., Snow, E. T., \& Tanaka, A. (2003). Arsenic and heavy metal contamination of vegetables grown in Santa village, Bangladesh. Science of the Total Environment, 308, 83-96. http://dx.doi.org/10.1016/S0048-9697(02)00651-4

Amdur, M. O., Doull, J., \& Classen, C. D. (1991). The Basic Science of Poisons 1. Soil Sci., 49, 639-64.

ATSDR. (2010). Agency for Toxic Substances and Disease Registry. Toxicological Profile for Arsenic (Draft). U.S. Public Health Service, U.S. Department of Health and Human Services, Atlanta, GA. Retrieved from http://www.atsdr.cdc.gov/toxfaqs

Chukwuma Sr., C. (1993). Comparism of the accumulation of $\mathrm{Cd}, \mathrm{Pb}$ and $\mathrm{Zn}$ in cultivated and wild species in derelict Enyigba lead-zinc mine. Toxicology and Environmental Chemistry, 38, 167-173. http://dx.doi.org/10.1080/02772249309357888

Clark, R. B. (1992). Marine Pollution (pp. 61-79). Oxford, UK: Cleavendo Press.

Clemson University. (1994). Extension service issued in furtherance of co-operative Extension work in Agriculture and Home Economics (5th edition, pp. 17-23).

Demirezen, D., \& Ahmet, A. (2006). Heavy metal levels in vegetables in turkey are within safe limits for $\mathrm{Cu}, \mathrm{Zn}$, $\mathrm{Ni}$ and exceeded for $\mathrm{Cd}$ and $\mathrm{Pb}$. J. Food Qual., 29, 252-265. http://dx.doi.org/10.1111/j.1745-4557.2006.00072.x

Galadima, A., \& Garba, Z. N. (2012). Heavy Metals Pollution in Nigeria: Causes and Consequences. Elixir Pollution, 45, 7917-7922.

Ismail, B. S., Farihah, K., \& Khairiah, J. (2005). Bioaccumulation of heavy metals in vegetables from selected agricultural areas. B. Environ. Contain. Tax., 74, 320-327. http://dx.doi.org/10.1007/s00128-004-0587-6

Jennings, T. C. (2005). Cadmium Environmental Concerns. PVC Handbook (p. 149). Hanser, Verlag.

Kaplan, M., Orman, S., Kadar, I., \& Koncz, J. (2005). Heavy Metal Accumulation in Calcareous Soil and Sorghum Plants after Addition of Sulphur-Containing Waste as a Soil Amendment in Turkey. Agric. Ecosyst. 
Environ., Ill, 41-46.

Karunakara, U. (2012, December 25). Lead poisoning and remediation in Zamfara. Retrieved from http://www.punchng.com/opinion/lead-poisoning-and-remediation-in-zamfara

Mattina, M. J., Berger, W. L., Musante, C., \& White, I. C. (2006). Concurrent plant uptake of heavy metals and persistent organic pollutants from soil. Environmental Pollution, 124, 375-378. http://dx.doi.org/10.1016/S0269-7491(03)00060-5

Miroslav, R., \& Vladimir, N. B. (1999). Practical Environmental Analysis (pp. 284, 314 and 357). Royal Society of Chemistry. UK.

Morishima, H., \& Oka, H. (1980). The Impact of Copper Pollution on Water Foxtail (Alopecurns aequalis Sobol) Populations and Winter Weed Communities in Rice Fields Agro-Ecosystems, 6, 33-49. http://dx.doi.org/10.1016/0304-3746(80)90004-9

Muhammad, F., Farooq, A., \& Umer, R. (2008). Aappraisal of Heavy Metal Contents in different Vegetables Grown in the Vicinity of an Industrial Area. Pak. J. Bot., 40(5), 2099-2106.

Nweke. F. N., Okaka, A. N. C., \& Offor, E. C. (2008). Lead, zinc and pH concentrations of Enyigba soil in Abakaliki Local Government Area of Ebonyi State, Nigeria. African journal of Biotechnology, 7(14), 2441-2443.

Occupational Safety and Health Administration (OSHA). (2005). Copper: Occupational Heavy Metal, U.S. Department of Labor, Washington D.C, (Vol. 11, pp. 30-62). Retrieved from http://www.osha.gov/SLTC/metalsheavy/copper.html

Oti, W., Nwabue, F., \& Afiukwa, J. (2012). Analysis of Heavy metals in soils of Enyigba and Abakaliki Using Proton Induced X-ray Emission (PIXE) Spectroscopy. Environment and Pollution, 1(2), 183-193.

Sawidis, T., Chettri, M. K., Papaionnou, A., Zachariadis, G., \& Stratis. J. (2001). A study of Metal Distribution from Lignite Fuels Using Trees as Biological Monitors. Ecotox. Environ. Safe, 48, 27-35. http://dx.doi.org/10.1006/eesa.2000.2001

Sharma, R. K., Agrawal, M., \& Marshall, F. (2006). Heavy Metals Contamination in Vegetables Grown in Wastewater Irrigated Areas of Varanasi. India B. Environ. Contain. Tax., 77, 312-318. http://dx.doi.org/10.1007/s00128-006-1065-0

Shefsky, S. (1995). Comparing Field Portable X-Ray Fluorescence (XRF) to Laboratory Analysis of Heavy Metals in Soil. Retrieved from http://www.clu-in.org/download/char/dataquality/sshefsky02.pdf

Singh, B. (2001). Heavy Metals in Soils: Sources, Chemical Reactions and Forms. In D. Smith, S. Fityus, \& M. Allman (Eds, pp. 77-93), GeoEnvironment: Proceedings of the 2nd Australia and New Zealand Conference on Environmental Geotechnics: Newcastle, New South Wales.

Taiwo, T. A. (1985). Sundrying of Fruits, Vegetables, Grain, Legumes Root and Tuber Crops in Nigeria-Problems and Prospects. Retrieved from www.fao.org/docrep

USEPA. (2010). Integrated Risk Information System. Retrieved from http://www.epa.gov/ncea/iris 